\title{
Analisis PIECES Pada Aplikasi WebGIS Pemetaan Ekonomi Kreatif (Ekraf)
}

\author{
Hetty Meileni ${ }^{* *}$, Sony Oktapriandi², Desi Apriyanti ${ }^{3}$ \\ ${ }^{1,2,3}$ Program Studi Manajemen Informatika, Politeknik Negeri Sriwijaya, Palembang, Sumatera Selatan \\ Email: ${ }^{1 *}$ hmeileni@gmail.com, ${ }^{2}$ sony.oktapriandi@gmail.com, ${ }^{3}$ aprilananda@yahoo.com
}

(Naskah masuk: 25 Sep 2020, direvisi: 20 Okt 2020, diterima: 23 Okt 2020)

\begin{abstract}
Abstrak
Ekonomi kreatif (Ekraf) merupakan salah satu faktor utama dalam peningkatan perekonomian. Ekonomi kreatif sering dikenal dengan istilah industri kreatif yang merupakan realisasi dari kreativitas dan keterampilan individu. Perkembangan ekonomi kreatif yang begitu pesat menciptakan sinergi yang tak terpisahkan dengan UKM (Usaha Kecil Menengah). Propinsi Sumatera Selatan memiliki ekonomi kreatif yang dapat dijadikan andalan, sektor fasyen dan kuliner menjadi andalan utama dalam peningkatan ekonomi. Ekraf dan UKM merupakan kekuatan tersendiri dalam menggerakan roda perekonomian daerah. Berdasarkan data yang didapat dari Badan Pusat Statistik tahun 2016 jumlah usaha Ekraf yang ada di Propinsi Sumatera Selatan berjumlah 156.322 dan saat ini Pemerintah Propinsi Sumatera Selatan belum mempunyai sebuah sistem atau aplikasi yang dapat digunakan untuk memetakan semua sektor ekonomi kreatif yang ada. Untuk melakukan pemetaan Ekraf yang ada perlu dibuat aplikasi pemetaan Ekraf di Propinsi Sumatera Selatan. Agar aplikasi ini dapat diimplementasikan secara maksimal dan terhindar dari kesalahan baik program maupun aplikasinya, maka perlu dibuat analisis dengan menggunakan metode PIECES sehingga aplikasi ini dapat diterapkan pada Dinas Perindustrian Sumatera Selatan dan dapat digunakan oleh masyarakat umum terkait perkembangan Ekraf yang ada di Propinsi sumatera selatan.
\end{abstract}

Kata Kunci: PIECES, aplikasi, pemetaan, Ekraf, UKM.

\section{PIECES Analysis on Creative Economy Mapping WebGIS Application}

\begin{abstract}
The creative economy is one of the main factors in developing the economy. The creative economy is often well known as the creative industry, which is the realization of the creativity and skills of individuals. The development of the creative economy rapidly creates an inseparable synergy with "UKM" (Usaha Kecil Menengah) or "Small to Medium Sized Business". South Sumatra Province has a creative economy that can be used as a mainstay, a fashion sector, and culinary which are being the main point of economic improvement in South Sumatra Province. Economy Creative and Small to Medium Sized Business are being the strength in moving the regional economy. Based on data that is obtained from the Central Bureau of Statistics in 2016, the number of Creative Economy businesses in South Sumatra Province is 156,322 and currently, the South Sumatra Government has not had a system or application yet which can be used to map out all existing creative economy sectors. To map the existing of Economy Creative needs to be developed the mapping application of Economy Creative in South Sumatra Province. To make this application be implemented optimally and avoided errors in both the program and the application so, it needs to make analysis by using the PIECES method. Furthermore, this application can be applied to the South Sumatra Industry Office and can be used by the public in case the development of Economy Creative in South Sumatra Province.
\end{abstract}

Keywords: PIECES, application, mapping, creative economy, small to medium sized business. 


\section{PENDAHULUAN}

Propinsi Sumatera Selatan mempunyai beberapa andalan ekonomi kreatif (Ekraf) yang telah bersinergi bersama UKM. Sektor kuliner dan fesyen merupakan potensi ekonomi Ekraf yang cukup dapat dibanggakan. Produk fesyen yang dapat diandalkan diantaranya adalah songket, kain tajung, dan batik jumputan khas kota Palembang. Sedangkan di sektor kuliner masing-masing daerah mempunyai andalan sendiri, misalnya di daerah Ogan Komering Ilir potensi Ekraf di sektor kuliner adalah keripik ubi. Di kota Palembang sendiri potensi Ekraf di sektor kuliner adalah pempek, kemplang dan kerupuk. Produk songket saat ini telah dikenal di mancanegara dan menjadi ikon kota Palembang. Tidak hanya songket, kuliner pempek, kemplang, dan kerupuk juga telah dikenal oleh masyarakat luas, baik di dalam maupun luar negeri.

Perkembangan Ekraf di Propinsi Sumatera Selatan berkembang pesat. Berdasarkan data yang didapatkan dari Badan Pusat Statistik tahun 2016, jumlah Ekraf yang ada di Propinsi Sumatera Selatan berjumlah 156.322, dimana terdiri dari 376 PT/Persero, $382 \mathrm{CV}, 6.089$ telah mempunyai izin khusus, 210 berbentuk badan usaha lain, dan 149.265 tidak berbadan usaha. Sedangkan total berdasarkan subsektor Ekraf saat ini sektor kuliner memiliki peringkat tertinggi yaitu $72,38 \%$ dan posisi kedua adalah sektor fesyen yaitu $15,44 \%$. Hal ini membuktikan bahwa Ekraf di Propinsi Sumatera Selatan sangat berkembang pesat. Sinergi antara Ekraf dan UKM tak terpisahkan dalam mengembangkan potensi ekonomi di Propinsi Sumatera Selatan. Saat ini Propinsi Sumatera Selatan belum memiliki aplikasi pemetaan Ekraf yang bersinergi bersama UKM yang dapat memetakan berdasarkan wilayah. Untuk itu perlu dibuat aplikasi pemetaan yang berisikan data-data koordinat, alamat, dan informasi pelaku Ekraf dan juga produk yang dikembangkan. Selain itu aplikasi ini juga memiliki fitur bagi para pelaku UKM dalam mengenalkan produknya ke masyarakat luas. Melalui aplikasi ini nantinya potensi Ekraf dan UKM dapat termonitor dengan baik. Aplikasi pemetaan ini diharapkan dapat meningkatkan potensi ekonomi kreatif Propinsi Sumatera Selatan dengan melihat peta persebaran untuk masing-masing sektor Ekraf berdasarkan wilayah yang ada. Dengan adanya aplikasi pemetaan Ekraf diharapkan sektor yang mempunyai persentase cukup kecil menjadi perhatian khusus bagi Propinsi Sumatera Selatan agar dapat ditingkatkan. Aplikasi yang dibangun nantinya akan dianalisis mengenai keadaan aplikasi tersebut mulai dari semua fitur yang ada sampai kinerja aplikasi. Untuk menganalisis kinerja sistem maka diperlukan sebuah metode. Metode analisis PIECES diperlukan dalam membangun aplikasi ini agar pemetaan Ekraf dapat diterapkan dan diimplementasikan secara maksimal tanpa adanya kesalahan, baik program maupun aplikasinya.

Analisis PIECES digunakan untuk mendapatkan hal-hal utama yang spesifik [1]. PIECES juga digunakan untuk menganalisis permasalahan yang ada, dengan mengidentifikasi permasalahan yang ada mengenai performance atau kinerja sistem informasi, ekonomi, keamanannya, efisiensi dan pelayanan untuk pengguna [2].
PIECES mempunyai enam kriteria yaitu Performance, Information, Economic, Control/security, Efficiency dan Service [3]. Aplikasi WebGIS pemetaan Ekraf yang dibangun harus memiliki enam kriteria dalam PIECES, kinerja aplikasi atau sistem yang baik, informasi yang terdapat pada aplikasi WebGIS pemetaan Ekraf harus valid, dan memiliki keamanan yang baik sehingga tidak mudah diakses oleh pihak-pihak yang tidak memiliki hak akses. Efisiensi aplikasi pemetaan ekonomi harus sesuai, serta layanan yang ditawarkan oleh aplikasi harus baik dan fleksibel.

Dengan digunakannya analisis PIECES diharapkan nantinya dapat memberikan penilaian tentang aplikasi yang akan digunakan. Hasil analisis dengan metode PIECES dapat menjadi pedoman dalam mengembangkan fitur-fitur yang ada pada aplikasi WebGIS pemetaan Ekraf sehingga dapat diimplementasikan dan digunakan untuk pelaku Ekraf yang bersinergi bersama UKM.

\section{LANDASAN TEORI}

A. Analisis

Analisis masalah adalah sebuah tahapan yang mendefinisikan ruang lingkup sistem. Tahapan ini mempelajari sistem yang ada dan menganalisis masalah yang ada untuk dicari pemecahan masalahnya [4].

Analisis terhadap sistem adalah melakukan evaluasi terhadap permasalahan-permasalahan yang ada agar dapat dilakukan perbaikan [5].

\section{B. Metode PIECES}

Metode PIECES digunakan untuk mendapatkan permasalahan yang ada terhadap sistem. PIECES terdiri dari performance, information, economic, control, efficiency, dan service. Dengan melakukan analisis PIECES ditentukanlah masalah utamanya agar dilakukan perbaikan. Enam variabel dalam PIECES yaitu [6]:

1. Analisis Kinerja Sistem (Performance)

Dilakukan untuk mengetahui kinerja sebuah sistem, kinerja didapatkan seberapa cepat data ditampilkan.

2. Analisis Informasi (Information)

Analisis ini digunakan untuk mengetahui seberapa jelas informasi yang didapatkan ketika dilakukan pencarian pada sistem yang dibuat.

3. Nilai Ekonomis (Economics)

Analisis ini dilakukan untuk menilai suatu sistem dari sisi ekonominya atau biaya. Seberapa besar biaya yang dikeluarkan untuk membangun sebuah sistem.

4. Analisis Pengamanan dan Pengendalian (Control)

Perlu dilakukan pengawasan agar sistem dapat berjalan dengan baik.

5. Analisis Efisiensi (Efficiency)

Sistem yang baik adalah yang mampu bekerja secara efektif dan efisien. Penggunaan menu atau fitur pada suatu sistem menentukan efisiensi sebuah sistem.

6. Analisis Pelayanan (Service)

Suatu sistem akan berjalan dengan baik jika diimbangi dengan pelayanan yang baik. Suatu sistem idealnya 
memiliki fitur layanan yang menjembatani pengguna dan pengelola sistem sehingga terjadi interaksi sistem yang baik.

PIECES merupakan sebuah alat yang digunakan untuk menilai kelayakan sistem. Kriteria-kriteria yang tercantum didalam PIECES dapat digunakan untuk melihat pengembangan sistem yang akan dilakukan, sehingga ketika sistem tersebut diimplementasi terbebas dari kesalahankesalahan sintaks dan program [7].

\section{WebGIS}

WebGIS merupakan sebuah aplikasi gabungan antara web design dan web pemetaan. Penggunaan teknologi WebGIS digunakan untuk menampilkan peta wilayah tertentu yang dilengkapi dengan penjelasan terhadap objek yang dipilih. Dengan menggunakan WebGIS, data wilayah tersaji dengan jelas dan lokasi dapat ditampilkan sehingga mempermudah dalam pencarian alamat [8].

Arsitektur WebGIS mempunyai 3 lapisan yaitu support layer, service layer, dan client layer [9].

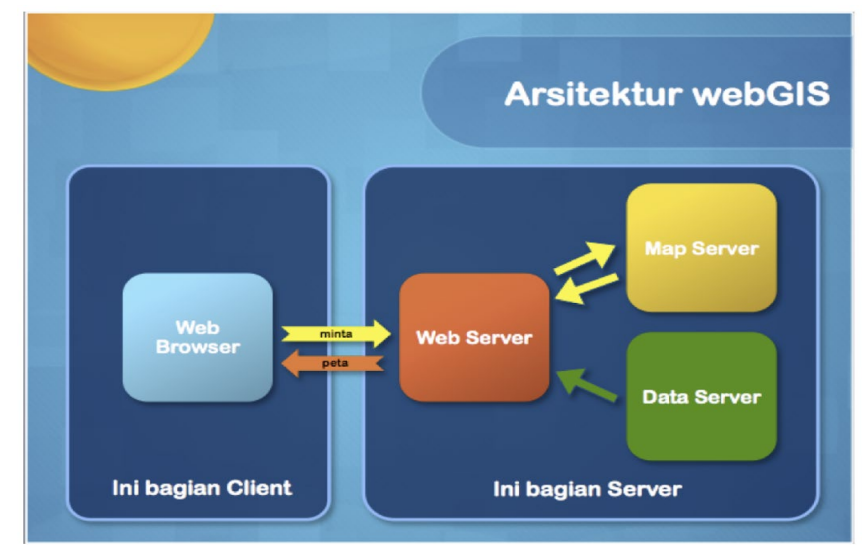

Gambar 1. Arsitektur WebGIS

Pada Gambar 1 menjelaskan proses permintaan data dari server ke client, dimana web client melakukan permintaan kepada server, kemudian web server akan mencari data yang diminta pada map server dan memberikan peta yang diminta ke web client [10]. Arsitektur WebGIS akan diterapkan dalam pembangunan aplikasi pemetaan Ekraf ini.

\section{METODE PENELITIAN}

Metode penelitian yang digunakan yaitu penelitian deskriptif kualitatif. Penelitian ini digunakan untuk mencari solusi dari permasalahan yang ada dengan menguraikan keadaan yang ada.

Metode pengumpulan data yang dilakukan yaitu:

1. Observasi

Observasi dilakukan pada Dinas Perindustrian, Propinsi

Sumatera Selatan. Observasi dilakukan dengan melihat sistem yang ada sebelumnya dan mencatat alur sistem yang ada. Saat ini Dinas Perindustrian, Propinsi Sumatera selatan belum memiliki aplikasi pemetaan WebGIS yang bersinergi dengan UKM. Metode pencatatan data Ekraf dan UKM dicatat dengan menggunakan aplikasi Microsoft Word dan Excel. Metode observasi yang dilakukan akan mendapatkan permasalahan yang ada untuk kemudian dilakukan pemecahan masalah sesuai dengan kebutuhan yang ada.

2. Kuesioner

Metode kuesioner dilakukan untuk mengumpulkan data dengan memberikan beberapa pertanyaan kepada responden. Kuesioner diberikan kepada staf yang ada di Dinas Perindustrian, Propinsi Sumatera Selatan.

3. Wawancara

Wawancara dilakukan untuk mendapatkan kelebihan dan kelemahan aplikasi yang dibangun yaitu aplikasi WebGIS pemetaan Ekraf.

\section{HASIL DAN PEMBAHASAN}

A. Metode Pengujian

Pengujian dilakukan dengan uji usabilitas. Untuk melakukan analisis terhadap aplikasi WebGIS pemetaan Ekraf dilakukan dengan membagikan kuesioner kepada staf Dinas Perindustrian, Propinsi Sumatera Selatan. Pertanyaan yang diberikan mengenai penggunaan aplikasi WebGIS pemetaan Ekraf yang meliputi performance, information, economic, control, efficiency, dan service. Daftar pertanyaan untuk masing-masing kategori analisis PIECES dapat dilihat pada Tabel 1, 2, 3, 4, 5 dan 6. Untuk pengukuran kuesioner menggunakan metode Likert's. Penyebaran kuesioner dilakukan secara online dengan menggunakan Google Forms kepada staf Dinas Perindustrian, Propinsi Sumatera Selatan. Jumlah pertanyaan pada kuesioner berjumlah 23 pertanyaan yang terbagi menjadi 6 kategori sesuai kategori analisis PIECES.

Bobot kuisioner yang digunakan adalah skala 1-5:

\begin{tabular}{|c|c|}
\hline $\mathrm{SS}=$ Sangat Setuju & bobot \\
\hline$S=$ Setuju & bobot \\
\hline $\mathrm{CS}=$ Cukup Setuju & bobot \\
\hline TS = Tidak Setuju & bobot \\
\hline STS $=$ Sangat Tidak Setuju & bobot \\
\hline
\end{tabular}

Berikut pertanyaan yang diberikan sesuai dengan analisis yang diberikan:

1. Pertanyaan kategori Performance

Tabel 1. Pertanyaan Analisis Performance

\begin{aligned} & No \multicolumn{1}{c}{ Pertanyaan } \\ & \hline 1 Aplikasi mudah dibuka \\ & \hline 2 Akses cepat ketika menu dibuka \\ & \hline 3 Tampilan peta tidak menutup konten \\ & \hline 4 Menu aplikasi mudah dipahami \\ & \hline\end{aligned}

2. Pertanyaan kategori Information 
Tabel 2. Pertanyaan Analisis Information

\begin{aligned} & \hline No \multicolumn{1}{c}{ Pertanyaan } \\ & \hline 1 Informasi mudah dipahami \\ & \hline 2 Informasi lengkap \\ & \hline 3 Terdapat panduan bagi pengguna \\ & \hline\end{aligned}

3. Pertanyaan kategori Economic

Tabel 3. Pertanyaan Analisis Economic

\begin{aligned} & \hline No \multicolumn{1}{c}{ Pertanyaan } \\ & \hline 1 $\begin{array}{l}\text { Aplikasi WebGIS Ekraf memudahkan pencarian } \\ \text { informasi }\end{array} \\ &$\hline 2 Hasil pencarian valid dan akurat \\ & \hline 3 $\begin{array}{l}\text { Aplikasi WebGIS Ekraf memiliki menu interaksi } \\ \text { dengan pengguna }\end{array} \\ &$\hline 4 $\begin{array}{l}\text { Aplikasi WebGIS Ekraf menyelesaikan } \\ \text { pekerjaan lebih cepat }\end{array} \\ &$\hline\end{aligned}

4. Pertanyaan kategori Control

Tabel 4. Pertanyaan Analisis Control

\begin{aligned} & \hline No \multicolumn{1}{c}{ Pertanyaan } \\ & \hline 1 $\begin{array}{l}\text { Aplikasi tidak menyebabkan komputer rusak atau } \\ \text { bermasalah }\end{array} \\ &$\hline 2 $\begin{array}{l}\text { Aplikasi tidak mengalami system error ketika } \\ \text { diakses }\end{array} \\ &$\hline 3 Halaman admin terpisah dengan halaman utama \\ & \hline 4 Aplikasi bebas virus \\ & \hline\end{aligned}

5. Pertanyaan kategori Efficiency

Tabel 5. Pertanyaan Kategori Efficiency

\begin{aligned} & \hline No \multicolumn{1}{c}{ Pertanyaan } \\ & \hline 1 Aplikasi WebGIS sesuai dengan kondisi yang ada \\ & \hline 2 Aplikasi sinergi dengan UKM \\ & \hline 3 $\begin{array}{l}\text { Aplikasi WebGIS Ekraf memberikan solusi bagi } \\ \text { Ekraft dan UKM }\end{array} \\ &$\hline 4 $\begin{array}{l}\text { Aplikasi WebGIS Ekraf dapat dijadikan } \\ \text { pengambilan keputusan bagi Dinas Perindustrian } \\ \text { Propinsi Sumatera Selatan }\end{array} \\ &$\hline\end{aligned}

6. Pertanyaan kategori Service

Tabel 6. Pertanyaan Analisis Service

\begin{tabular}{cl}
\hline No & \multicolumn{1}{c}{ Pertanyaan } \\
\hline 1 & $\begin{array}{l}\text { Terdapat menu panduan untuk penggunaan } \\
\text { aplikasi }\end{array}$ \\
\hline 2 & $\begin{array}{l}\text { Terdapat fitur yang digunakan untuk pencarian } \\
\text { informasi }\end{array}$ \\
\hline 3 & Terdapat menu pendaftaran bagi Ekraf dan UKM \\
\hline 4 & Terdapat menu saran dan kritik bagi pengguna \\
\hline
\end{tabular}

B. Metode Analisis Sistem

Metode analisis sistem menggunakan PIECES. Adapun tahapan-tahapan analisis yang dilakukan sebagai berikut:

\section{Performance}

Performance merupakan hal yang sangat penting dalam sebuah aplikasi atau sistem, dimana performance menunjukkan kinerja sistem secara nyata. Performance memperlihatkan sebuah sistem dapat diakses dengan cepat. Terkadang tampilan website yang sangat menarik membutuhkan waktu akses cukup lama. Sistem yang baik yaitu yang memberikan kecepatan yang maksimal ketika diakses. Untuk melihat performance pada aplikasi WebGIS pemetaan Ekraf diperlukan sebuah pengujian agar didapatkan hasil apakah aplikasi WebGIS pemetaan Ekraf performance nya sudah baik. Aplikasi pemetaan Ekraf berbasis WebGIS ini dapat diakses melalui laman http://Ekrafsumsel.com/. Tampilan aplikasi WebGIS pemetaan Ekraf dapat dilihat pada Gambar 2.
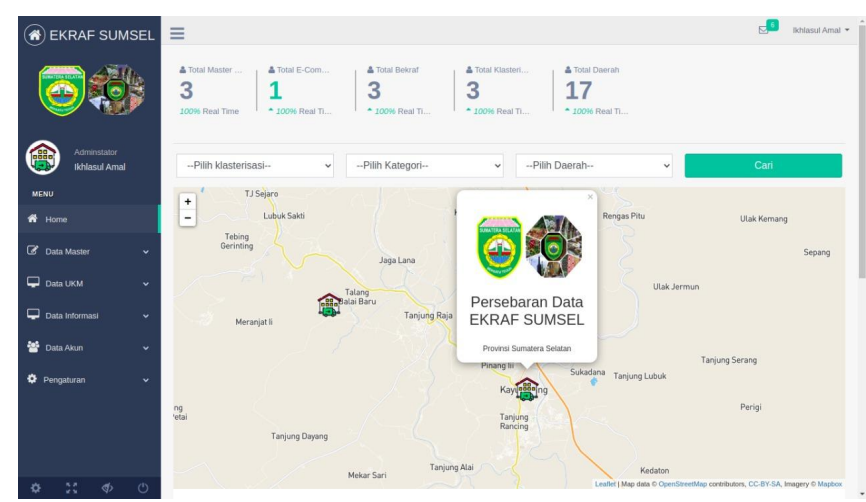

Gambar 2. Tampilan Aplikasi WebGIS Pemetaan Ekraf

Pada Gambar 2 menampilkan pemetaan Ekraf yang tersebar di beberapa wilayah Propinsi Sumatera Selatan. Pengguna dapat melakukan pencarian data Ekraf berdasarkan klasterisasi, daerah, dan kategori Ekraf. Sebagai tool penunjang yang digunakan untuk melakukan analisis performance pada aplikasi WebGIS pemetaan ekonomi kreatif yaitu menggunakan Google PageSpeed Insight melalui laman https://developers.google.com/speed/pagespeed/ insight

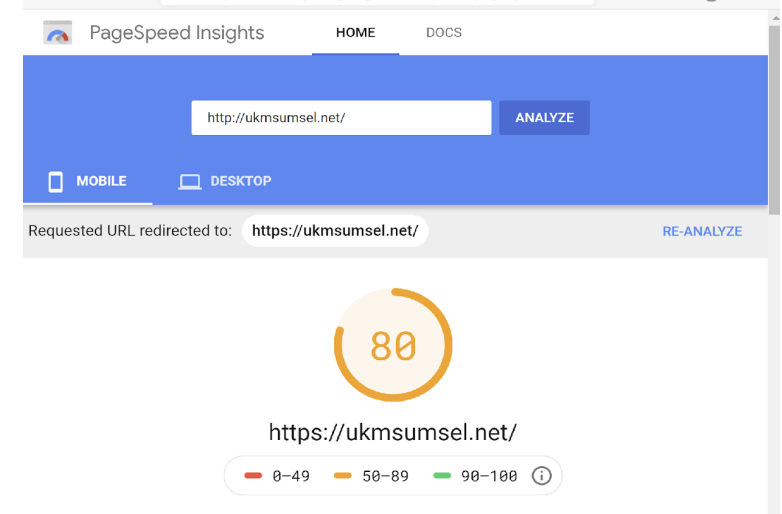

Gambar 3. Tampilan Hasil Analisis Performance 
Gambar 3 menampilkan hasil analisis performance yang dilakukan dengan menggunakan Google PageSpeed Insight. Hasil analisis menunjukkan nilai 80 . Hal ini menyatakan dari sisi kinerja aplikasi pemetaan Ekraf berjalan dengan baik. Untuk melihat hasil performance secara detail dapat dilihat pada Gambar 4 di bawah ini.

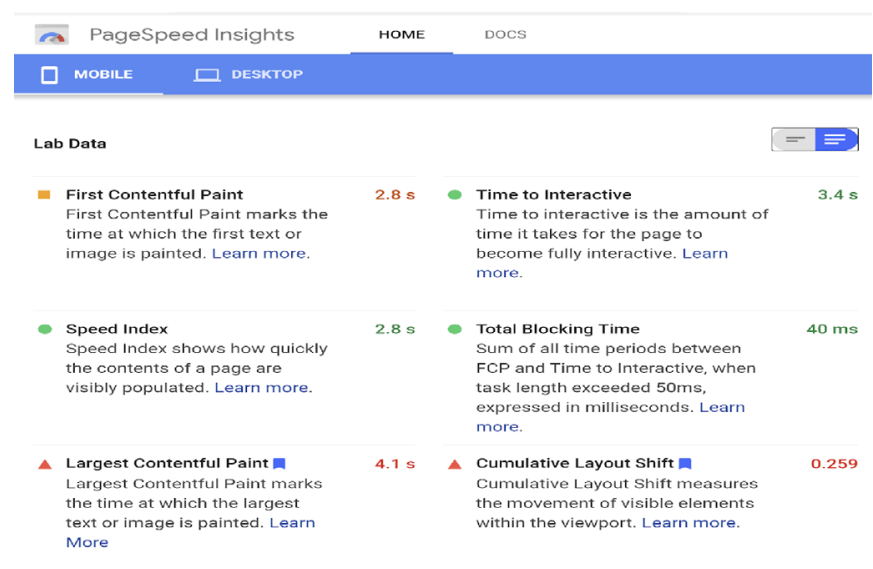

\section{Gambar 4. Tampilan Detail Hasil Analisis Performance}

Dari hasil analisis yang dilakukan didapatkan bahwa kecepatan dalam mengakses aplikasi WebGIS pemetaan Ekraf mendapatkan nilai 80 atau B, dimana kecepatan pertama kali pada saat aplikasi dibuka (first contentful paint) adalah 2,8 detik, speed index menunjukkan seberapa cepat content terbuka di setiap halaman yang ada yaitu 2,8 detik, kecepatan membuka gambar (largest contentful paint) yang ada yaitu 4,1 detik, kecepatan saat user berinteraksi dengan sistem memilih fitur yang ada (time to interactive) yaitu 3,4 detik, jumlah keseluruhan waktu ketika interaktif terjadi dan melakukan penyimpanan yaitu 40 mili detik, dan total keseluruhan waktu untuk proses perpindahan gerak atau gambar secara otomatis (cumulative layout shift) yaitu 0,259 .

Berdasarkan pengukuran yang telah dilakukan bahwa aplikasi WebGIS pemetaan Ekraf dalam kecepatan akses pertama kali sudah terkategori Baik (B), agar performance dapat ditingkatkan lagi maka perlu diperbaiki lagi dalam hal penggunaan gambar yang ada.

\section{Information}

Pada tahapan analisis information yang dilakukan yaitu menganalisis kebutuhan-kebutuhan yang ada di Dinas Perindustrian, Propinsi Sumatera Selatan. Berdasarkan hasil penyebaran kuesioner yang dilakukan kepada staf Dinas Perindustrian, Propinsi Sumatera Selatan didapatkan nilai 4,.2 yaitu baik. Informasi yang disajikan di dalam aplikasi WebGIS sesuai dengan kondisi yang sebenarnya. Selain itu aplikasi ini juga memberikan informasi tentang UKM yang ada dimana perkembangan Ekraf telah bersinergi dengan UKM. Informasi yang ditampilkan tidak hanya sebatas pemetaan saja tetapi juga sebagai wadah bagi para pelaku UKM untuk mengenalkan produknya ke masyarakat. Berdasarkan analisis inilah secara keseluruhan informasi telah dinilai baik. Gambar 5 menampilkan informasi yang ada di aplikasi pemetaan Ekraf.

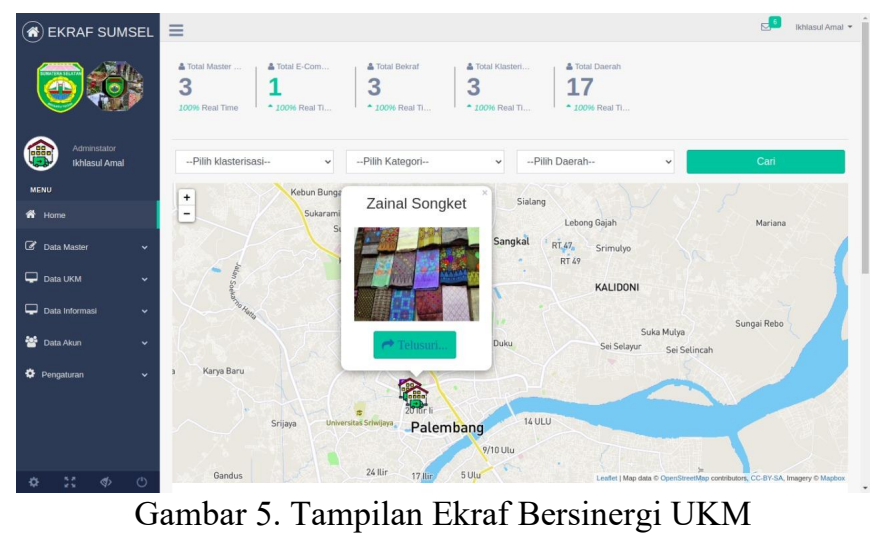

Pada Gambar 5 menampilkan berapa banyak data Ekraf yang ada, total e-commerce yang ada, total klaster yang ada, dan total daerah yang memiliki Ekraf. Halaman ini menampilkan peta wilayah Ekraf. Pengguna dapat melakukan filter data Ekraf yang terdiri dari beberapa kategori Ekraf. Filterisasi ini menampilkan informasi Ekraf, untuk melihat informasi detail mengenai data Ekraf yang dipilih user dengan menekan tombol telusuri seperti terlihat pada Gambar 5. Fitur telusuri akan memberikan informasi detail tentang Ekraf yang dicari bahkan dapat menampilkan toko Ekraf yang tergabung di dalam e-commerce UKM.

\section{Economics}

Pada tahapan analisis ekonomi yang dilakukan yaitu menganalisis keterkaitan biaya dengan informasi yang diberikan pada aplikasi. Berdasarkan hasil kuesioner yang diberikan kepada Dinas Perindustrian, Propinsi Sumatera Selatan secara keseluruhan mendapatkan nilai baik (B). Pada aplikasi WebGIS pemetaan Ekraf terdapat menu yang digunakan untuk mendaftar sebagai pelaku UKM agar dapat memasarkan produknya. Dengan adanya menu pendaftaran ini masyarakat tidak perlu harus datang ke Kantor Dinas Perindustrian, Propinsi Sumatera Selatan untuk melakukan pendaftaran sebagai pelaku Ekraf yang bersinergi dengan UKM. Fitur e-commerce ini dapat diakses oleh pelaku UKM yang sudah tervalidasi oleh Dinas Perindustrian, Propinsi Sumatera Selatan. UKM yang belum terdaftar tidak dapat mengakses fitur ini. Dengan adanya validasi memberi jaminan tersendiri pagi pengguna dalam melakukan transaksi pembelian online.

Gambar 6 menampilkan pelaku UKM yang telah bersinergi dengan Ekraf. Melalui fitur ini UKM memiliki sebuah wadah dalam memasarkan produknya di bawah pengawasan Dinas Perindustrian, Propinsi Sumatera Selatan. Pada halaman ini pengguna dapat melakukan pembelian online dengan memilih produk-produk UKM. Proses pembelian dapat dilakukan kapan saja tanpa ada batasan jarak dan waktu. Dengan adanya fitur ini diharapkan dapat meningkatkan penjualan pelaku UKM. 


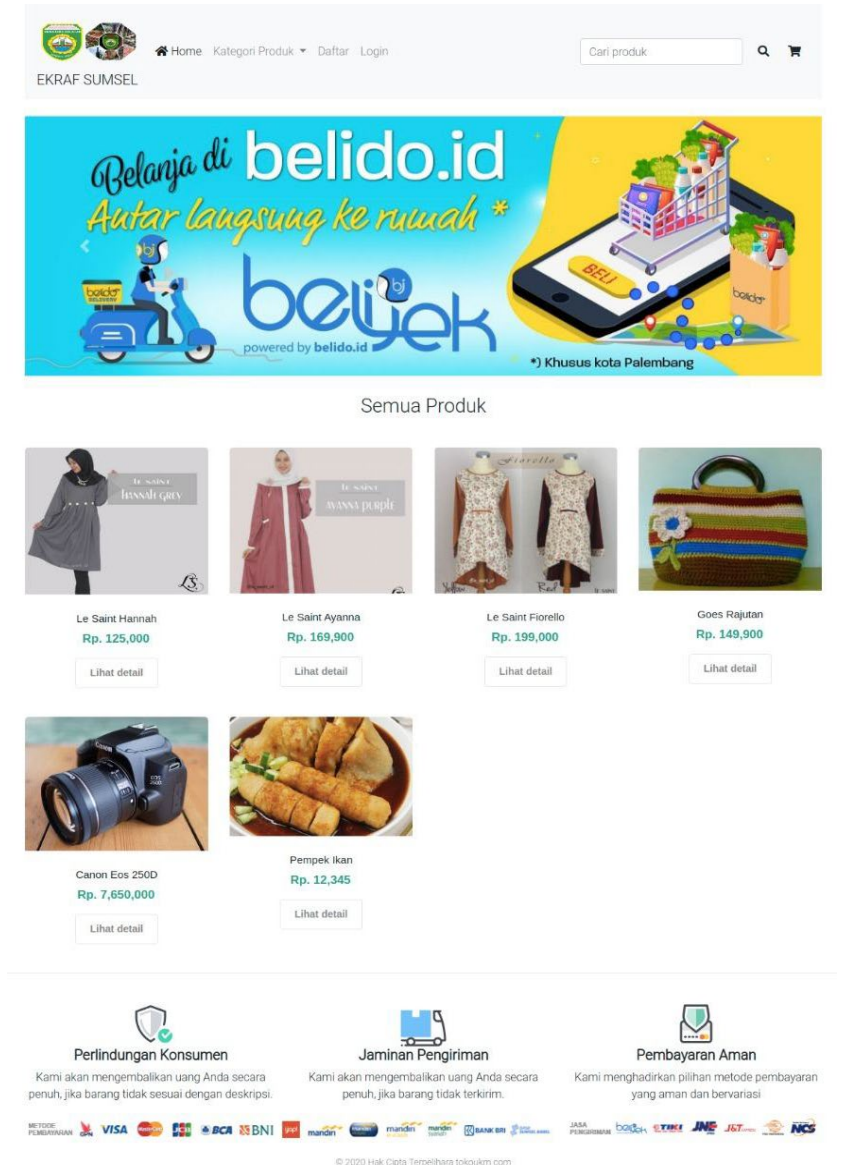

Gambar 6. Tampilan Fitur UKM

\section{Control}

Pada tahapan analisis control yang dilakukan yaitu menganalisis keamanan aplikasi WebGIS pemetaan Ekraf. Berdasarkan hasil kuesioner yang telah disebarkan kepada Dinas Perindustrian, Propinsi Sumatera Selatan aplikasi dinilai baik (B). Dilihat dari segi konten aplikasi WebGIS pemetaan sangat mudah dipahami. Aplikasi memberikan kemudahan bagi pengguna untuk menggunakannya atau dapat juga disebut aplikasi bersifat user friendly. Pengaturan posisi gambar isi dan bentuk huruf yang digunakan juga sudah sangat baik. Analisis control lebih difokuskan pada keamanan aplikasi dari serangan virus yang dapat mengganggu kinerja komputer.

Pada tahapan control ini diukur juga keamanan aplikasi dengan menggunakan tool Qualys yang dapat diakses melalui laman https://www.ssllabs.com/ssltest/ hasil analisis control dapat dilihat pada Gambar 7.

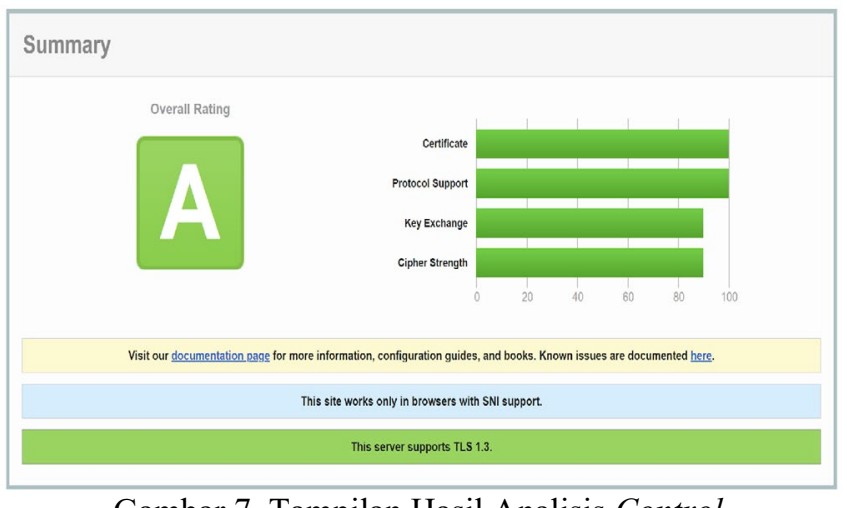

Gambar 7. Tampilan Hasil Analisis Control

Gambar 7 menampilkan hasil analisis control. Dari hasil analisis control yang dilakukan aplikasi pemetaan Ekraf mendapatkan peringkat A yang berarti penilaian control sangat baik, aplikasi tidak mengandung kesalahan program.

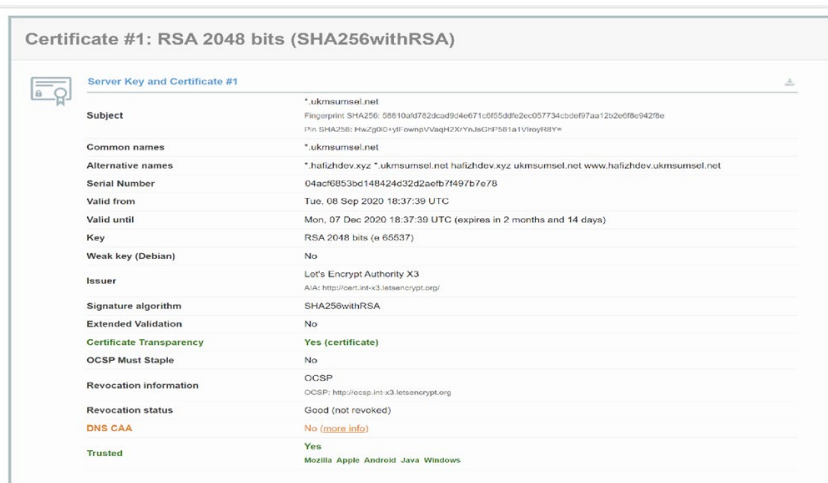

Gambar 8. Tampilan Hasil Analisis Control Secara Detail

Gambar 8 menampilkan kesimpulan hasil analisis control, terlihat bahwa aplikasi pemetaan Ekraf ini dapat dipercaya hal ini dibuktikan dengan adanya keterangan Trusted: Yes.

Dari hasil analisis control dapat disimpulkan bahwa aplikasi WebGIS pemetaan Ekraf aman untuk diakses oleh masyarakat atau pengguna bebas.

\section{Efficiency}

Analisis efficiency dilakukan untuk menganalisis tingkat efisiensi yang diberikan oleh aplikasi WebGIS pemetaan Ekraf. Dari hasil kuesioner yang disebarkan kepada staf Dinas Perindustrian, Propinsi Sumatera Selatan untuk informasi yang ditampilkan memberikan manfaat bagi pengguna. Aplikasi WebGIS pemetaan Ekraf memiliki efisiensi yang baik (B). Aplikasi yang dibangun memberikan informasi dan juga output sesuai yang diinginkan. Untuk efisiensi diharapkan lebih ditingkatkan lagi agar mendapatkan nilai sangat baik dengan memberikan informasi yang lengkap.

\section{Service}

Analisis service dilakukan untuk melihat layanan-layanan yang diberikan oleh aplikasi WebGIS pemetaan Ekraf. Berdasarkan hasil kuesioner untuk analisis service menghasilkan nilai baik (B). Aplikasi telah memberikan 
layanan yang dibutuhkan oleh pengguna, mulai dari peta Ekraf, sinergi Ekraf dan UKM, tidak hanya sebatas pemetaan saja aplikasi ini juga memberikan pelayanan bagi pelaku UKM untuk mendaftarkan produknya sehingga dapat dikenal masyarakat luas. Untuk meningkatkan layanan aplikasi harus memiliki menu live chat, agar dapat berkomunikasi dan berdiskusi dengan administrator aplikasi, selain itu aplikasi juga sebaiknya memiliki fitur untuk dapat menampung saran dan kritik dari pengguna.

\section{Hasil Pengujian Sistem}

Berdasarkan pengujian yang telah dilakukan dengan menggunakan analisis PIECES, hasil pengujian secara keseluruhan dapat dilihat pada Tabel 7 dibawah ini.

Tabel 7. Hasil Pengujian Dengan Metode PIECES

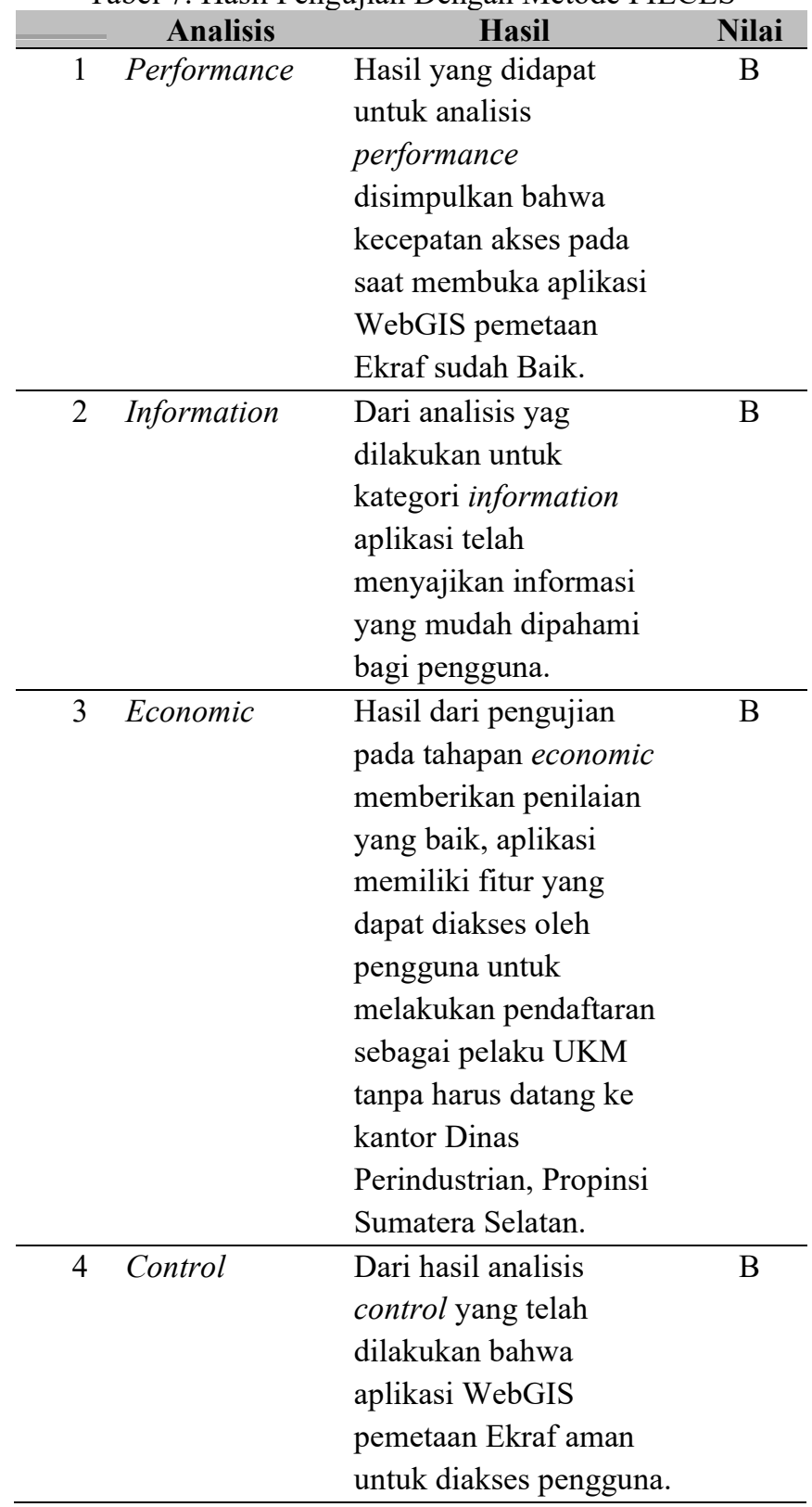

\begin{tabular}{lll}
\hline 5 Efficiency & Aplikasi WebGIS & B \\
& pemetaan Ekraf & \\
& memiliki efisiensi yang & \\
& baik dibuktikan dengan & \\
& adanya informasi yang & \\
& dinilai sudah lengkap \\
& oleh pengguna. & \\
& Hasil analisis untuk & B \\
& service dinilai baik oleh \\
& pengguna karena telah \\
& memiliki layanan yang \\
& dapat diakses oleh \\
& pengguna terutama \\
& pelaku Ekraf yang \\
& bersinergi dengan UKM \\
& hal ini dibuktikan \\
& dengan adanya fitur bagi \\
& pelaku UKM dalam \\
& memasarkan produknya \\
\hline &
\end{tabular}

\section{KESIMPULAN}

Berdasarkan pembahasan di atas telah dilakukan tahapan tahapan penelitian dengan melakukan analisis menggunakan metode PIECES maka dapat disimpulkan bahwa metode PIECES dilakukan untuk menganalisis apakah aplikasi WebGIS pemetaan Ekraf dapat diimplementasikan di Dinas Perindustrian, Propinsi Sumatera Selatan. Secara keseluruhan dari hasil analisis dengan menggunakan metode PIECES mulai dari kategori Performance, Information, Economics. Control, Efficiency, dan Service, aplikasi pemetaan WebGIS Ekraf menghasilkan nilai yang baik. Hal ini dapat disimpulkan bahwa aplikasi ini dapat diterapkan.

Untuk pengembangan agar menjadi lebih baik lagi disarankan pada aplikasi pemetaan Ekraf terdapat fitur untuk memberikan informasi secara detil mengenai lokasi Ekraf, sehingga mempermudah pengunjung mencari alamat jika ingin berkunjung membeli produk Ekraf secara langsung. Aplikasi pemetaan Ekraf diharapkan nantinya dapat melakukan perangkingan Ekraf sehingga potensi Ekraf pada masing-masing daerah dapat terpantau secara maksimal dan yang belum berpotensi dapat ditingkatkan lagi. Dari segi efficiency aplikasi ini dapat dikembangkan lagi dengan menambah fitur-fitur yang lebih lengkap mulai dari detail wilayah secara geografis sampai pada rute atau jarak masingmasing Ekraf sehingga dapat diketahui lokasi Ekraf untuk masing-masing daerah melalui koordinat yang diberikan. Aplikasi pemetaan Ekraf selanjutnya dapat dikembangkan lagi menjadi aplikasi mobile sehingga dapat diakses oleh berbagai perangkat mobile. 


\section{REFERENSI}

[1] Dwiyantaro. (2019). Analisis Dan Evaluasi Penerapan Sistem Informasi Smart Library Amikom Resource Centre Dengan Metode PIECES Framework. TIK ILMEU: Jurnal Ilmu Perpustakaan dan Informasi, Vol. 3(2), pp. 109-124.

[2] Nurjamiyah \& Dewi, A.R. (2018). Analisis Sistem Informasi Pengolahan Data Nilai Mahasiswa Menggunakan PIECES Pada Prodi Sistem Informasi STTH-Medan. Query: Jurnal Sistem Informasi, Vol. 2(2).

[3] Fattah, H.A.L. (2008). Analisis Dan Perancancangan Sistem Informasi. Yogyakarta: Andi Offset.

[4] Adiguna, A.R., Saputra C.M. \& Pradana F. (2018). Analisis dan Perancangan Sistem Informasi Manajemen Gidang Pada PT Mitra Pinasthika Mulia Surabaya. Jurnal Pengembangan Teknologi Informasi dan Ilmu Komputer, Vol. 2(2), pp. 612-621.

[5] Jogiyanto. (2009). Analisis dan Desain Sistem. Yogyakarta: Andi Offset.
[6] Sholeh, M. \& Maulanan, T. (2015). Desain Dan Implementasi Sistem Informasi Wisata Goa Berbasis Google Map. Jurnal Teknologi dan Sains Terapan SIMETRIS, Vol.9(1), pp. 20-27.

[7] Lestari, A.S. \& Hamka, S.R. (2019). Analisis PIECES dalam Implemetasi Kebijakan E-Learning di IAIN Kendari. Jurnal Manajemen Pendidikan Islam, Vol. 4(1), pp. 103-125.

[8] Arikunto \& Suharsimi. (2014). Prosedur Penelitian: Suatu Pendekatan Praktik. Jakarta: Renika Cipta.

[9] Pamungkas, R. (2019). Evaluasi Kualitas Website Program Studi Sistem Informasi Universitas PGRI Madiun Menggunakan Webqual 4.0. Jurnal Intensif, Vol. 3(1), pp. 22-31.

[10] Saputra, A.A., Ramdani, F. \& Suprapto. (2018). Pembangunan Arsitektur WebGIS Untuk Pemetaan Daerah Yang Terdampak Erupsi Gunung Merapi (Studi Kasus: Kabupaten Sleman). Jurnal Pengembangan Teknologi Informasi dan Ilmu Komputer, Vol.2(9), pp. 3233-3244. 